\title{
Impact of the COVID-19 Pandemic to the Sustainability of the Energy Sector
}

\author{
Indre Siksnelyte-Butkiene
}

check for

updates

Citation: Siksnelyte-Butkiene, I. Impact of the COVID-19 Pandemic to the Sustainability of the Energy Sector. Sustainability 2021, 13, 12973.

https://doi.org/10.3390/su132312973

Academic Editor: Alberto-Jesus Perea-Moreno

Received: 3 November 2021

Accepted: 21 November 2021

Published: 23 November 2021

Publisher's Note: MDPI stays neutral with regard to jurisdictional claims in published maps and institutional affiliations.

Copyright: (C) 2021 by the author. Licensee MDPI, Basel, Switzerland. This article is an open access article distributed under the terms and conditions of the Creative Commons Attribution (CC BY) license (https:// creativecommons.org/licenses/by/ $4.0 /)$.
Business Faculty, Kaunas University of Applied Sciences, Pramones av. 20, LT-50468 Kaunas, Lithuania; indre.siksnelyte@knf.vu.lt

\begin{abstract}
In order to control the COVID-19 pandemic, the governments of the world started to implement measures regarding social distance and social contacts, including closures of cities, work and study relocations, and work suspension. The epidemical situation and the lockdown of the economy by governments in various countries caused changes in production, changes in the habits of energy consumers and other energy-related changes. This article analyses the impact of the global pandemic on the energy sector and the relationship with the progress to the sustainability of the energy sector. The systematic literature review was performed in the Web of Science (WoS) database. The research follows recommendations of the SALSA (Search, Appraisal, Synthesis and Analysis) and PRISMA (Preferred Reporting Items for Systematic Reviews and Meta-Analyses) approaches. A total of 113 relevant articles were selected for the analysis. All selected articles were categorized according to their application and impact areas. The five main impact areas of the COVID-19 pandemic to the sustainability of the energy sector were identified: consumption and energy demand; air pollution; investments in renewable energy; energy poverty; and energy system flexibility. Based on the current research findings and perception of the problem, the main insights for future research in the field are provided.
\end{abstract}

Keywords: COVID-19; energy sector; sustainability; low-carbon; renewable energy; energy poverty; pandemic

\section{Introduction}

The World Health Organization announced a global pandemic of COVID-19 caused by coronavirus SARS-CoV-2 in March 2020 [1]. In order to control the situation, world governments started to implement measures regarding social distance and social contacts, including the closure of cities, work and study relocations, and work suspension. Some implemented measures caused economical lockdown and led the world economy into decline. The epidemical situation and lockdown of the economy by governments in different countries of the world caused changes in production, changes in the habits of energy consumers and other energy related changes. The recent studies show that more than $80 \%$ of workplaces were partly or fully closed in 2020 [2], electricity demand increased in households [3], world energy demand decreased [4], people reduced mobility by more than 50\% [5], public transport was the most affected [6], and air transport was suspended in many countries [7]. According to the prognosis of the International Energy Agency [8], energy related $\mathrm{CO}_{2}$ emissions will fall by around $7 \%$ and new investments will decrease by around $18 \%$.

The effect of the pandemic on the energy sector has attracted a lot of attention in the scientific literature. Energy demand changes caused by the COVID-19 pandemic are strongly related to the implementation of a low-carbon economy, the daily life of local communities, the profitability of utility companies, national and global climate targets and the state of the environment. Numerous studies were carried out to examine the effects of COVID-19 on different aspects of the energy sector. The multiple effects of the COVID19 pandemic have been discussed in only a few studies. Bompard et al. [9] presented a 
systemic approach for the examination of the effects of the COVID-19 pandemic on the energy sector. The approach was applied for the assessment of the European power system. The authors distinguished between direct and indirect impact. The indirect impact is related to the technical operation of energy systems and changes in energy markets. Direct impact is related to changes in energy demand (consumption profile and energy mix). The implications of the pandemic for the electricity sector was analyzed in the study by Zhong et al. [10]. The impact on the electricity demand, share of renewables, power balance, uncertainty of the demand, and challenges for management were identified. In order to investigate pandemic responses on energy grid dynamics in Europe, Werth et al. [11] performed an analysis in sixteen countries. According to the results, the restrictions caused the load drop and energy generation was affected in most countries. The results also showed that energy generation from nuclear, coal and gas sources decreased significantly, while penetration of renewables is increasing. Navon et al. [12] analyzed the effects of the pandemic on electric power grids and energy systems and identified the new challenges caused by the pandemic. The authors presented patterns of power demand and generation, load forecasting, and frequency deviations. However, the studies mainly analyze the linkages between one specific issue and the pandemic.

The current paper seeks to review previous studies and to identify the impacts of COVID-19 on the sustainability of the energy sector. It provides a broad map of the problem, gives solid background for further research and can help for scholars to conduct further studies. The systematic literature review follows recommendations of the SALSA (Search, Appraisal, Synthesis and Analysis) [13] and PRISMA (Preferred Reporting Items for Systematic Reviews and Meta-Analyses) [14]. The scientific literature search was performed in the Web of Science (WoS) database and covers the last two years (from March 2020 to the end of October 2021). A total of 113 relevant studies, which analyzed and measured the impact of the COVID-19 pandemic to the issues on the sustainability of the energy sector, were reviewed; the main insights are presented in this study.

The methodology of the systematic literature review is presented in the Section 2 of the article. The Section 3 presents a detailed analysis of studies dealing with the effects of the COVID-19 pandemic on the sustainability of the energy sector issues. The main results and discussion are provided in the Section 4.

\section{Methodology}

The systematic literature review was carried out according to the recommendations of the SALSA [13] and PRISMA [14]. The search was carried out on the combination of the topics "COVID" and "energy" in the WoS Core Collection database. The inclusion criteria for the content analysis were applied in the appraisal step. The inclusion criteria were as follows: all keywords are in the title, abstract or keyword section; article is published in a scientific peer-reviewed journal; article is in the Energy Fuels WoS category; article is published in English. The abstract reading and content analysis were performed for 238 articles. Only studies which directly respond to the problem of the research were included in further analysis. Finally, 113 articles were selected for further analysis and included in the review. The methodological framework of the systematic literature review is presented in Figure 1:

In order to give a broad overview of reviewed studies, the general information about them is presented in Table 1. 
Table 1. The general information of reviewed studies.

\begin{tabular}{|c|c|c|c|c|}
\hline Impact Areas & Application Areas & Methods Used & Case Studies Locations & $\begin{array}{c}\text { Years of } \\
\text { Publications }\end{array}$ \\
\hline $\begin{array}{ll}\text { - } & \text { Carbon emissions/air } \\
\text { pollution } \\
\text { - } \\
\text { Investments in } \\
\text { renewables } \\
\text { - } \quad \text { Consumption and } \\
\text { habits } \\
\text { - } \quad \text { Energy poverty } \\
\text { Energy system } \\
\text { flexibility }\end{array}$ & $\begin{array}{ll}- & \text { Energy mix } \\
- & \text { Energy demand } \\
- & \text { Energy poverty } \\
- & \text { Economic } \\
& \text { uncertainty } \\
-\quad & \text { Mobility } \\
-\quad & \text { Energy system } \\
& \text { flexibility }\end{array}$ & $\begin{array}{ll}- & \text { General equilibrium model } \\
- & \text { Machine learning approaches } \\
- & \text { Econometric analysis } \\
- & \text { Multi-criteria analysis } \\
- & \text { Different forecasting techniques } \\
- & \text { Global vector autoregressive } \\
\text { - } & \text { Codelling } \\
-\quad & \text { The life cycle assessment }\end{array}$ & $\begin{array}{l}\text { China, South Korea, Japan, } \\
\text { Taiwan, India } \\
\text { - Turkey, Bangladesh, Serbia, } \\
\text { Kuwait } \\
\text { - } \quad \text { The UK, Ukraine, Norway } \\
\text { - } \quad \text { Brazil, Chile, Argentine } \\
\text { - } \quad \text { Australia } \\
\text { - The EU countries } \\
\text { - Kenya, Ethiopia } \\
\text { - Multiple countries }\end{array}$ & $\begin{array}{ll}- & 2022(2) \\
- & 2021(97) \\
- & 2020(14)\end{array}$ \\
\hline
\end{tabular}

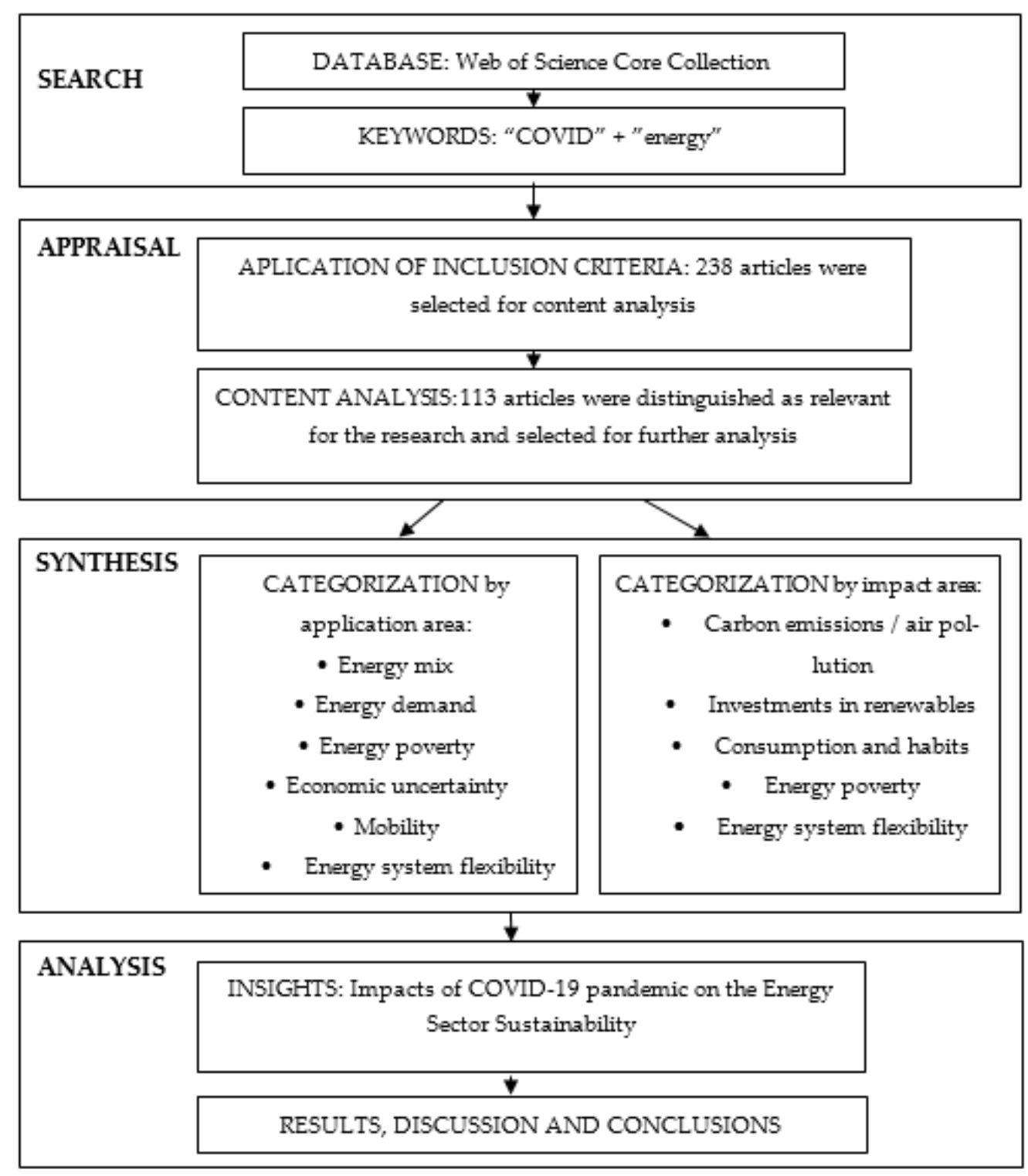

Figure 1. The methodological framework of the review.

\section{Literature Review}

The detailed analysis of studies allowed us to identify the main impact areas of the COVID-19 pandemic for the sustainability of the energy sector. Categorization of studies by their application and impact area is presented in Table 2. The main results of the research 
dealing with changes of air quality, investments in renewable energy, energy consumption, energy poverty and energy system flexibility are presented in the following sub-sections.

Table 2. Categorization of studies by application and impact areas.

\begin{tabular}{|c|c|c|c|c|c|c|}
\hline Impact & Energy Mix & Energy Demand & Energy Poverty & $\begin{array}{l}\text { Economic } \\
\text { Uncertainty }\end{array}$ & Mobility & $\begin{array}{c}\text { Energy System } \\
\text { Flexibility }\end{array}$ \\
\hline $\begin{array}{c}\text { Carbon } \\
\text { emissions/air } \\
\text { pollution }\end{array}$ & [15-23] & {$[16,23-28]$} & {$[17,23,29]$} & {$[26,30-38]$} & {$[16,25,39-44]$} & \\
\hline $\begin{array}{l}\text { Investments in } \\
\text { renewables }\end{array}$ & {$[18,20,45-57]$} & {$[46,58,59]$} & [46] & $\begin{array}{c}{[26,30-32,38,46,48-} \\
52,60-67]\end{array}$ & {$[40,44,68]$} & [69] \\
\hline Consumption & {$[9,11,19,22,23,70-78]$} & $\begin{array}{r}{[3,9,11,21,27,28,45} \\
55,58,59,72,74-108]\end{array}$ & {$[17,23,109]$} & $\begin{array}{c}{[9,11,28,34,35,73,99,} \\
110-113]\end{array}$ & {$[16,39,41,44,80,110,114]$} & {$[75,78]$} \\
\hline Energy poverty & & & {$[109,115-119]$} & {$[46,118]$} & & \\
\hline Reliable supply & & & & {$[34,46,120,121]$} & & {$[69,75,78,121-123]$} \\
\hline
\end{tabular}

\subsection{Impact on Air Pollution}

The COVID-19 pandemic has had devastating consequences on both health and the economy in the last two years. At the same time, the restrictions and lockdown of economic activities were followed by a decrease in energy consumption and reduction in polluting emissions.

The research results by Wang et al. [24,45] show that the pandemic has had positive significant impact on the state of air. The better air quality in China is related to the number of confirmed cases of COVID-19 illness and death. It can be assumed that the number of cases and deaths is also related to the restrictions imposed in the country by the government. These studies reaffirm that economic activity has a significant impact on air pollution. Also, Han et al. [79] measured air pollution during the pandemic in selected sites in China and found clear links between potential emission resources and air quality. The concentration of emissions dropped significantly. The relationship between energy demand and air quality has been proven in many articles. According to the study by Shang et al. [80], the reduction in energy consumption and emissions in Beijing (China) was followed by huge environmental benefits. In order to analyze the environmental impact of the decrease in fossil fuel use in 2020, Rashedi et al. [15] applied the life cycle assessment approach. The significant environmental improvements were identified in the research.

The relationship between air pollution and the transport sector during the pandemic has been analyzed in several studies. Gurbuz et al. [39] assessed the impact of the pandemic to the fuel consumption for road transport and for several environmental and economical indicators in Turkey. According to the results, the level of fuel consumption decreased significantly. This decrease subsequently affected the decrease in air pollution. The significantly reduced emissions in the transport sector during the lockdown showed a real example of what may happen if behavioral change would be more sustainability-oriented. However, it is necessary to highlight the fact that political interventions are necessary to encourage the behavioral changes in the society [40]. New and effective technologies cannot, by themselves, solve the issues of the environment; the public acceptance and behavioral changes of the society are crucial. The study by Hu et al. [114] shows that attitude towards the environment and economic and safety benefits are the main aspects impacting the acceptance of shared electric cars in China. According to the study, the information about the economic and social benefits should be advertised and consideration of the protection of the environment should be encouraged. Kylili et al. [41] sought to identify indicators that would allow countries to deal with environmental and energy challenges for the transition to smart energy cities and regions in Europe. According to the simulations for the case of Cyprus, the remote work can save at least $4 \mathrm{~L}$ of transport fuel and $7.4 \mathrm{~kg}$ of $\mathrm{CO}_{2}$ emissions per hour per 100 employees. The environmental improvement due to the reduction in air transport during the pandemic has been proven by the analysis in a study by Nizetic [42]. 
The opposite considerations were provided in the study by Schulte-Fischedick et al. [43]. The authors examined passenger mobility during the COVID-19 lockdowns in Europe. The results showed that the use of public transport has decreased and the use of private transport has increased significantly. These trends are contradictory to major climate goals in Europe. The increase in energy consumption in the transport sector was identified in the research by Lalas et al. [25]. The authors analyzed the energy consumption and GHG emissions changes in Greece during the pandemic. According to the results, energy consumption in electricity and heating were reduced; however, energy consumption related to transport was increased. Overall, the total amount of energy usage was decreased and GHG emissions were reduced during the pandemic.

Part of the studies were designed to highlight opportunities for the improvement of the state of the air and the environment after the COVID-19 pandemic. Maniatis et al. [30] considered changes to the global economy and energy sector in the context of COVID-19 and discussed the opportunities to implement the 2050 targets of the Paris Agreement. In order to investigate the possibility of achieving the Paris Climate Agreement targets, Teske et al. [31] used normative scenarios. According to the projections, the delay in the implementation of climate goals would significantly decrease the likelihood of achieving the 1.5 degrees C goal. Chiaramonti and Maniatis [110] analyzed the usage of transport during the pandemic and stressed the importance of taking the opportunity to meet climate goals in the post-COVID 19 era. Rochedo et al. [32] analyzed recovery packages of the post COVID-19 era. Maestosi et al. [33] discussed funding opportunities and new frameworks for the development of sustainable urban areas in the context of Covid-19 in order to achieve Horizon Europe plans by 2030. According to the modelling results, climate actions and investments in the development of green energy and in the reduction of carbon emissions should be significantly up-scaled. According to the study by Su and Urban [16], the COVID-19 pandemic provides an opportunity to initiate circular economy measures. The authors modelled the energy and emissions scenarios and projected a clean energy transition for a city in China.

The relationship between the energy poverty of different groups of people and $\mathrm{CO}_{2}$ emissions in developing countries was analyzed in the study by Huang and Tian [29]. The authors used the hypothetical extraction method and analyzed eight developing countries. The results showed that, despite the decrease in emissions inequality during the COVID-19 pandemic, emissions inequality will still exist in the future. In order to achieve progress in this regard, the targeted poverty measures should be implemented. Martinez-Soto et al. [17] examined the relationship between energy poverty and air pollution during the COVID-19 lockdowns in south-central Chile. According to the results, middle-income households increased air pollution by using more wood for heating purposes. While low-income and energy-poor households used less wood for energy generation and subsequently decreased the level of air pollution they emit

\subsection{Impact on Investments in Renewables}

Although the pandemic can act as an accelerator for the decarbonization of the economy and increase renewable energy generation by replacing fossil fuels, the pandemic affected the consumption of energy and the supply chain of renewables. The difficulties in manufacturing and the troubles in exports [60] caused a contraction in the renewable energy sector. Gebreslassie [46] analyzed the situation of solar energy during the pandemic in Ethiopia. It was found that COVID-19 brought big challenges to solar energy development in the country. First of all, the pandemic caused a decrease in solar technologies end-users' income; second, a lot of businesses were forced to close. The lack of technologies supply affected the development of renewable energy. At the same time, it affected the development of energy access in remote areas. Wang et al. [61] applied complex network theory and analyzed the global photovoltaic cell trade in the period of 2000-2019. According to the authors, the pandemic modified the relations and caused disruption risks to the global photovoltaic cell trade. The case study of offshore wind generation in China shows that 
the pandemic increased the cost of energy generation and decreased the profitability of investments [62]. In order to ensure stable development and achieve the minimum share of renewables in different provinces of China, Yu et al. [47] proposed a dispatching model for renewable energy. Shah et al. [18] analyzed the links between the pandemic, air quality, and electricity production from solar, wind, and nuclear energy in Sweden. It was determined that the pandemic slowed down the development of new wind projects due to difficulties in the supply. This affected air quality because it was not as improved as it could have been. Solar energy projects were not affected in the country.

Various papers determined the negative impacts of economic uncertainty on investments in renewable energy projects $[48,49,63,64]$. Zhang et al. [65] investigated the extent of solar photovoltaic market slowdown during the COVID-19 lockdown. The results showed that the monthly value-added loss was almost $70 \%$ and that the emission reduction capacity was decreased by almost $65 \%$ over the year. Shah et al. [50] examined the effect of the pandemic on renewable energy generation in Denmark. The authors applied advanced econometric framework and found that the generation of energy was negatively affected by the lockdown and by daily deaths from COVID-19. According to the authors, economic stability is an important factor for the development of renewable energy projects. Kudelin and Kutcherov [51] provided wind energy forecasts for Russia. According to the authors, the pandemic is a factor that can influence slow wind farm deployment in the country. Ziemba [52] applied multi-criteria evaluation for the identification of the most effective investments for wind development in Poland under uncertainty. Zeinalnezhad et al. [66] highlighted the importance of investments in renewable energy projects for the recovery of the post COVID-19 economy. The authors identified nine critical risks for wind farm development; all of them are strongly related to economic uncertainty. Political stability, the absence of sanctions, economic security, a stable interest rate, a stable exchange rate, a stable inflation rate, no feasibility risk, low capital risk, and low supplier risk are the main factors for the assessment of risk for wind farm development. According to Mohideen et al. [68], the current challenges of COVID-19 allow for the reshaping of the energy system, the rethinking of the initiatives used for renewable energy development and the lowering of future fossil fuel usage. The authors stressed the necessity to transform the transport sector and to invest in hydrogen and fuel cell technologies. Griffiths et al. [44] presented opportunities that the COVID-19 pandemic has created for sustainable mobility development. Saif-Alyousfi and Saha [67] examined the effect of the COVID-19 pandemic on the energy returns across more than a hundred global energy indices in thirty-four countries. The relationship between growth of confirmed cases and cases of death from the pandemic had a negative direct effect on global energy returns. The economic lockdown (closure and restrictions of workplaces) had a positive impact on global energy returns. Cancellation of public events, public transport restrictions, and campaigns of public information had a negative effect.

The lower price of crude oil during the COVID-19 pandemic had a significant negative impact on the low-carbon economy. The analysis of crude oil price is showing significant volatility and historical lows during the pandemic [19]. Some authors state that, despite the fact that the economic downturn has led to a decline in carbon emissions, the pandemic situation had changed oil price [19,70,124]. Nyga-Lukaszewska and Aruga [71] used the auto-regressive distributive lag technique for the analysis of oil and gas prices during the COVID-19 crisis. The authors analyzed market reactions during the first wave in the United States and Japan. According to the results, the pandemic negatively affected the price of crude oil and positively affected the gas price in the United States. The statistically negative affect on the crude oil price was also detected in Japan, while impact on gas price was not identified. Jia et al. [20] analyzed the impact of oil on the level of carbon emissions in China. According to the results, this situation has led to an increased use of fossil fuels and has delayed the development of renewable energy. According to the authors, environmental policy in the post-COVID-19 era should focus on the adjustment of the price gap between fossil fuels and renewable energy, where the carbon taxes and tax benefits for 
renewable energy can be the main instruments for change. Other studies also highlight the importance of investments in renewables in the face of the decrease in crude oil price. Andiappan et al. [53] analyzed the challenges for biomass energy development in the post COVID-19 era. Wang et al. [54] provided policy suggestions for the implementation of freemarket environmentalism in order to achieve the development of more efficient renewables in the post-COVID-19 era. De Blasis and Petroni [120] investigated price and volatility linkages between renewable energy and oil firms during the pandemic. The results of the analysis show that volatility increased in all energy firms, but is stronger for oil firms than for renewable firms. Other scientists provide contrary results. The results of the study by Dmytrow et al. [34] show that sources such as crude oil, heating oil, and gasoline have a weak relationship with the pandemic, while natural gas, ethanol, $\mathrm{CO}_{2}$ allowances, and palm oil have a strong association with the pandemic.

According to different studies, the pandemic did not have a negative effect on the share of the general energy mix that belongs to renewables. It has been observed that the penetration of renewables has increased. The results of the study by Sahin et al. [55] show that the share of renewable energy in total electricity generation will grow to the end of 2021 in selected European countries. In order to forecast energy consumption and renewable energy generation under the COVID-19 pandemic, the authors applied machine learning and seasonal grey models. The decline of non-renewable energy generated was identified, in some countries reaching as much as a quarter of the previous generation. Liu and Lin [58] applied multivariate time series prognosis with bidirectional long short-term memory for the identification of relationships between energy demand and lockdown measures, and between renewable energy supplies and weather conditions during the pandemic. According to the results, lockdown restrictions reduced energy demand in the United Kingdom. As energy consumption in the country was declining before the pandemic, the authors assumed that the pandemic will not have a negative impact on the share of renewable energy sources in the final energy mix. Furthermore, it is worth mentioning that the European parliament changed their ambition to reduce climate change and increased the target of reduction of GHG emissions from 55\% to 60\% compared to 1990 levels. This indicates the smooth development of investment in renewable energy in the region [56].

\subsection{Impact on Consumption and Habits}

Most studies used statistical data during the pandemic or lockdown period to determine the impact of COVID-19 on energy consumption changes. The decrease in energy demand during the lockdown in multiple countries of the World was calculated in the study by Rajan et al. [72]. Abdeen et al. [3] analyzed households in Canada and found that the consumption in electricity during the COVID lockdowns increased by about $12 \%$. The increase in the demand of electricity was mainly due to heating purposes. Furthermore, the results show that post-pandemic peaks are up to $20 \%$ higher than those pre-pandemic. The electricity demand decrease and shift in peak demand was determined in the study by Bielecki et al. [81], where electricity consumption in the residential sector in the capital of Poland during the COVID-19 lockdown was analyzed. Other study by Rouleau and Gosselin [82] evaluated the effect of the COVID-19 lockdown on the electricity, heating, and hot water consumption in Canada's residential sector. The results show that consumption patterns for hot water and electricity increased and were not concentrated in the evening, as they were before the lockdown. However, the analysis did not identify the changes in heating consumption. It can be assumed that the changes in heat consumption directly depend on the geographical data of the objects under the study. The importance of geographical features for energy changes during the pandemic has also been demonstrated in the study by Liu et al. [83]. The authors sought to determine the effect of the pandemic on the energy consumption habits of aged people. The biggest reduction of energy use was identified in warm regions. The temperate regions were distinguished by a time shift in peak demand, while energy consumption changes in hot regions were insignificant. 
Carvalho et al. [84] analyzed energy consumption trends in Brazil and found a significant decrease in consumption among different profiles of energy users, depending on geographic regions. The changes on households' energy consumption and activities were not only due to work activities at home, but also due to the education activities of minors' at home [85]. Snow et al. [86] found that a significant increase in household electricity consumption in Australia was directly related to the lockdowns. Also, the linkages between social distancing policy and ambient temperature and energy demand were identified in the study by Alkhraijah et al. [87]. Chen et al. [88] found that households used more energy during the pandemic, but only high-income households were more willing to pay for home energy management systems. The analysis of electricity consumption in Romania also showed a decrease in energy demand. The biggest decrease was found in the generation of electricity from coal and hydropower [73]. The analysis of statistical data from South Korea also showed a decrease in overall energy consumption [89], where the demand of electricity decreased more that $4 \%$ and the consumption of gas decreased more than $10 \%$. The study gives ordinary tendencies: energy consumption correlates with the COVID-19 pandemic; the consumption of energy in the commercial sector decreased, but it increased in the residential sector. Tsai [59] analyzed the changes of energy consumption and supply in Taiwan during the pandemic. The decrease in both indicators was identified $(4.3 \%$ and $4.7 \%$ respectively). Also, it was determined that petroleum consumption shows a decreasing trend; at the same time, the consumption of electricity has increased. The energy consumption behavior and the impact of the COVID-19 pandemic in a city of Spain was analyzed by Garcia et al. [90]. The authors proposed an approach for the analysis and examined smart meter data of energy consumers. According to the analysis, the consumption in the residential sector increased by around 15\% during the strict lockdown and half of this decrease was observed during the period of reopening. Also, the study presents the behavior of five non-residential groups of customers. The final conclusion of the study is that the behavior of each group of customers' directly correlates to the restrictions imposed. Two multi-criteria decision-making approaches were applied by Qarnain et al. [91] for the identification and analysis of factors influencing energy consumption during the COVID-19 pandemic in residential buildings in India. The social distancing, lockdown and home transformation (work and education at home) were the main factors influencing the changes in consumption. Furthermore, it was found that the lockdown of streets and public markets and psychological factors were also affecting the increase in energy consumption.

Other studies supplement and justify such results. Malec et al. [92] analyzed the influence of COVID-19 restrictions on the energy consumption of commercial users in Poland. The significant differences were observed among different sectors of the economy. The decrease in energy consumption was more than $20 \%$ during the first lockdown and more that $10 \%$ during the second. The projections of post-COVID industrial production in Italy show that the impact of the shock of the COVID-19 pandemic may continue to 2040, and may decrease total industrial energy consumption by 5\% [93]. The impact of the pandemic lockdown on the electricity consumption in Brazil municipal buildings was measured by Geraldi et al. [94]. The results of the study show that energy consumption was affected directly by the lockdown measures. The use of electricity reduced by around 10\% in health centres, by around $40 \%$ in administrative buildings, and by around $50 \%$ in nursery schools and elementary schools. Other factors influencing the changes in energy consumption are recommendations for living and work environments for buildings [95]. Usually, the institutions prepared recommendations without considering the energy efficiency of buildings and the climate condition.

The analysis of the linkages between changes in energy consumption and renewable energy penetration received attention in several studies currently under review. $\mathrm{Xu}$ et al. [74] examined the impact of the pandemic on the electricity demand and renewable energy penetration into the power grid in Japan. The results of the analysis showed a decrease in electricity demand, from $2 \%$ to $8 \%$ (depending on the region) and a time shift in peak demand. Due to reduced electricity demand, the penetration of re- 
newable energy into the public grids increased. The results obtained in the study by Halbrugge et al. [75] are similar. The authors analyzed the electricity demand in Germany and found a decrease in consumption. For this reason, the penetration of renewables in the grid rose. Sotnyk et al. [21] analyzed the "green and coal paradox" in Ukraine. The decrease in electricity export during the COVID-19 lockdowns encouraged governments to implement renewable energy goals and to decrease nuclear energy in their country's energy mix. The rapid changes in energy mix and the closure of cheap energy sources caused an increase in electricity prices. In addition, the share of fossil fuels increased in the country's energy mix.

The changes in the energy consumption and reduction of $\mathrm{CO}_{2}$ emissions during the lockdown period in India was detected by the study of Rajan et al. [72]. It was found that the energy demand increased in some regions of India and decreased in others during the lockdown. Such changes in energy consumption are linked to the economic and industrial development in each region, climatic conditions and the number of households. The study by Zhang et al. [26] shows that the lockdown affected energy consumption of commercial tourism cities and significantly reduced air pollution. Alhajeri et al. [27] performed an analysis of energy demand in Kuwait during the COVID-19 lockdown. A decrease in electricity of around $18 \%$ was found and the reduction of air pollution regarding less fuel consumption in power plants was determined.

In order to examine the impact of the pandemic on the European electricity markets, Drabecki and Kulak [76] analyzed statistical data before and during the pandemic. The significant impact on electricity demand and on share prices of energy companies was identified. Although the changes on energy price was not detected. Ghenai et al. [22] analyzed the changes in EU electricity generation mix during the lockdowns and its linkages to clean energy transition. The changes in fossil and renewable energy supply, energy demand, and GHG emissions were calculated by performing a statistical analysis of the data. According to the results, the decrease in energy demand has led to these changes in the energy mix: the share of fossil fuels decreased significantly, while the penetration of renewables has grown by up to $9 \%$. The case study of Italy by Ghiani et al. [77] showed similar results regarding the electricity demand and penetration of renewables. The reduced energy consumption and the average daily spot electricity prices in European countries was discussed by Strielkowski et al. [96]. According to the authors, effective management of energy consumption based on information and communication technologies will help to implement smart renewables-based grids. Other authors presented contrary results about the impact of the pandemic on energy prices. This was mainly due to the different periods under which the study took place. In order to determine the impact of pandemic on power demand and electricity prices, Hauser et al. [97] applied econometric analysis. According to the results, the COVID-19 pandemic decreased not only energy consumption, but also energy prices. The decrease in power prices were also identified in the study by Abadie [98]. According to the research by Bento et al. [28], the disruptions caused by pandemic lockdowns had a strong affect on the load consumption in Spain and Portugal. The study proved the effects observed in other studies in terms of energy consumption, generation mix, and electricity prices. Several indices have also been developed to predict the price of electricity under conditions of uncertainty. Norouzi et al. [99] presented a framework for prediction of electricity prices during shifting periods. Olubusoye et al. [111] introduced an information-based index for the forecasting of energy prices under uncertainty.

Other studies sought to examine the impact of the pandemic on economic growth and energy consumption. In order identify the relationship between gross domestic product and electricity consumption in Romania, Soava et al. [100] used a linear regression model. The significant impact of commercial energy consumption on gross domestic product in the pandemic was determined. $\mathrm{Hu}$ and $\mathrm{Li}$ [112] sought to examine the spillover effects of the United States' economic decline caused by COVID-19 on economic development and energy consumption in other countries. The authors applied a global vector autoregressive technique. Although the results of this study provided significant insights into the 
impact of the United States' economic situation on other countries' economic growth and energy consumption, the study is based on data between 1990 to 2013, which may differ significantly from the current situation of the global economy.

Many studies sought to predict future energy consumption using a different model of forecasting. Sozen et al. [101] applied three advanced machine learning approaches for the forecasting of energy demand and generation in Turkey. The authors predicted the share of electricity generated from natural gas and coal. The prognosis shows a $6 \%$ and $7 \%$ decrease, respectively, compared to the previous year. The prediction for energy demand in Turkey also was proposed by Ceylan [102]. Several advanced machine learning approaches were applied for the calculations and forecast of electricity demand. Bin Amin et al. [103] applied seasonal autoregressive integrated moving average model (SARIMA) for the forecasting results of electricity demand and generation in Bangladesh. The results show that the decrease in consumption will be $8-10 \%$ and $6 \%$ in the upcoming two years. Kim et al. [104] applied a machine learning model with artificial neural networks for the prediction of hot water demand in the residential sector in South Korea. The authors determined the changes in the increase in hot water demand by about $8-16 \%$. Lu et al. [105] presented a hybrid model for daily electricity demand forecasting in the context of the COVID-19 pandemic. The model is based on multi-objective optimizers and was applied for the case study of the United States. Huang et al. [113] presented a prediction method for the analysis of the gap in electricity consumption due to the pandemic. According to the results, the impact of the pandemic on electricity consumption is related to the local lockdown policies and measures implemented. Cvetkovic et al. [106] analyzed people's energy consumption behavior during the pandemic and used EnergyPlus software for the simulation of the consumption of electricity, natural gas and water in a few residential houses in Serbia. Bazzana et al. [35] tried to measure the possible effect of the COVID-19 pandemic to the energy sector in Italy. The authors applied a multidisciplinary approach and created different scenarios in order to forecast market reactions and energy consumption.

The results of the analysis of electricity consumption in Nordic countries differs. According to the Mauritzen [107], there was no decrease in energy consumption in Denmark and Sweden, although the peak hours changed. Significant reductions in energy prices have also been observed, but they started even before the COVID-19 restrictions were implemented. It should be noted that the Nordic countries have a uniquely high penetration of renewable energy.

Several authors discussed the environmental impacts of COVID-19 vaccination, environmental and energy footprints of fighting against pandemic $[36,108]$ and stressed the importance to implement the vaccination in a maximum sustainable way [37].

\subsection{Impact on Energy Poverty of Households}

The COVID-19 pandemic has caused big challenges for low-income people, especially those that suffer from energy poverty or face other risks. Another important aspect in identifying the impact of COVID-19 on the sustainability of the energy sector is to identify the linkages between the pandemic and the level of energy poverty of households.

Nagaj and Korpysa [115] identified the variables affecting energy poverty during the COVID-19 pandemic. The study examined the effect of the pandemic on the level of energy poverty in Poland. According to the results, financial difficulties, the pandemic situation and lockdowns had a negative impact on the disposable income of households. Also, the prices and expenditure on energy increased, which further boosted the required share to pay for energy bills. It can be concluded that the level of energy poverty in the country has increased and the most affected have been the low-income households. Similar results were obtained in the research by Mamica et al. [109]. The authors analyzed the factors influencing energy poverty among Polish students during the pandemic. Distance learning has changed the behavior and attitudes of students. The increase of overall living costs and inappropriate temperature due to big energy costs were the main factors that affected the increase of energy poverty among students. The inability to meet basic energy needs can 
have health consequences. Memmott et al. [116] found that the pandemic increased energy risk and energy poverty. Furthermore, it may have extended existing racial disparities among people suffering from energy poverty. The decline of households' income during the pandemic had affected the households' habits and possibilities to use clean energy in Kenya. According to the study by Shupler et al. [23], 95\% of households faced a decrease in income, which led to a change in cooking fuels to polluting ones (kerosene or wood). Ambrose et al. [117] analyzed the linkages between fuel poverty and the pandemic in the United Kingdom. The results showed that the number of fuel-poor households had risen by 600,000 during the pandemic period.

Graff and Carley [118] provided suggestions for decision-makers on how to fight against the potential growth of energy poverty among households in the context of the United States. Bienvenido-Huertas [119] analyzed the measures for alleviating energy poverty in order to reduce the risk of energy poverty among Spanish households during the lockdown. According to the study, the discount in the electricity bill based on the month and income would reduce the risk of falling into energy poverty.

\subsection{Impact on Energy System Flexibility}

The changes in daily life, the economy, energy and other sectors caused by the pandemic should not stop efforts to combat climate change. The transition to a low-carbon society and economy is mainly based through the development of renewable energy. Therefore, to ensure energy system flexibility is a challenge to each country's energy system.

The articles under the current literature review also stressed the importance to improve flexibility. According to observations in the study by Halbrugge et al. [75], the decrease in electricity consumption may have contributed to the stability of the grid. The importance to redesign the existing balancing mechanisms was stressed in the study by Kirli et al. [78]. The authors analyzed the impact of the COVID-19 lockdown on energy generation, demand, grid stability and price in the United Kingdom. As in earlier mentioned studies, the decrease in energy use, change in peak demand and increase in renewable energy penetration was detected.

Alvarez [122] introduced a multi-objective framework that enhances the operations of energy systems under COVID-19 circumstances. The presented framework considers geographical aspects that are affected by virus cases and their effects on the employees of power plants. Schwidtal et al. [69] analyzed the first months of the COVID-19 pandemic and provided insights for modelling future renewable energy scenarios. Heffron et al. [121] created the projections on possible impact of the pandemic for the economy and society in Europe and provided five policy recommendations for European countries in order to ensure energy system flexibility. Flexibility improvement measures under the COVID19 pandemic were provided in the study by Luo et al. [123]. The authors presented a comparative analysis in the Netherlands, Denmark, and a city in China (Sichuan).

\section{Results Overview and Discussion}

According to the results of the systematic literature review, most of the research analyzed how the pandemic changed energy demand. In addition, an interest on the impact of economic uncertainty to the investments in new renewable energy projects was observed. In the future, more attention should be paid to research dealing with the linkages between energy poverty and the pandemic. These connections are widely discussed in public and at the political level, but there is a lack of studies dealing with them. Table 3 provides the percentage distribution of research by their application and impact area.

The research findings of the systematic literature review identifying the impacts of the COVID-19 pandemic on the sustainability of the energy sector is presented in a graphical way in Figure 2: 
Consumption / energy demand

- Reduced overall energy consumption

- Energy demand increased in residental sector

- Energy demand decreased in commertial/industrial sector

- Time shift in peak demand

- Changes in consumption profiles of energy users

\begin{tabular}{c}
\hline Air pollution / air quality \\
$\qquad$ Overall better air quality is observed \\
- The share of fossil fuels decreased in energy mix \\
- Fuel consumption reduced in most countries \\
The use of private transport increased in Europe \\
Investments in renewable energy
\end{tabular}

The difficulties in technologies supply (manufacturing and export)

The decrease in the profitability of investments

The negative impact of economic uncertainty on investments in new projects

Energy poverty

Negative impact on the disposable income of households

The increase in prices and expenditure on energy

Energy system flexibility

- Decrease in energy use, change in peak demand, and increase in renewable energy penetration caused challenges for each country energy system

- New projections and models are required to ensure system flexibility

Figure 2. The impact of the COVID-19 pandemic on the sustainability of the energy sector.

Table 3. The research directions by identifying the impact of the COVID-19 pandemic to the the sustainability of the energy sector.

\begin{tabular}{ccccccc}
\hline & $\begin{array}{c}\text { Energy } \\
\text { Mix }\end{array}$ & $\begin{array}{c}\text { Energy } \\
\text { Demand }\end{array}$ & $\begin{array}{c}\text { Energy } \\
\text { Poverty }\end{array}$ & $\begin{array}{c}\text { Economic } \\
\text { Uncertainty }\end{array}$ & $\begin{array}{c}\text { Mobility } \\
\text { Flexibility }\end{array}$ & $\begin{array}{c}\text { Energy System } \\
\text { Flex }\end{array}$ \\
\hline Carbon emissions/air pollution & 7.96 & 6.19 & 2.65 & 8.85 & 7.08 & - \\
Investments in renewables & 13.27 & 2.65 & 0.88 & 16.81 & 2.65 & 0.88 \\
Consumption & 12.39 & 40.71 & 2.65 & 9.73 & 6.19 & 1.77 \\
Energy poverty & - & - & 5.31 & 1.77 & - & - \\
Reliable supply & - & - & - & 3.54 & - & 5.31 \\
\hline
\end{tabular}

The overall energy consumption decreased in many countries of the world. The research shows changes in the energy consumption profiles of energy users. Consumption in the household sector increased, but decreased in the commercial sector. It can be concluded that the decrease in energy consumption in commercial facilities has influenced the increase in energy demand in the household sector. The discussion question is whether companies pay for the additional energy costs incurred by their employees. However, households usually cover the costs of additional energy for their work needs from their own income. The changes in work and daily life of people changed the behavior of energy users, leading to a shift in peak demand.

The COVID-19 pandemic and lockdowns caused temporary effects in many sectors. Some changes can be long-term; for example, consumption and consumer behavior may remain changed and continue to change. Probably a big proportion of employees will continue to work remotely. Moreover, research shows that the quality of work has not suffered in many cases and, on the contrary, has even improved. The losing sectors, such 
as tourism and transportation, may suffer long-term consequences and difficulties with recovery. However, sectors based on information technologies have strengthened their positions in the market. These statements are only a small part of those that confirm that consumption priorities and the behavior of people will be different after the pandemic than before it. Therefore, countries need to reconsider and adapt their energy policy to the changed environment, as well as consumer habits and consumption of energy in order to effectively pursue the goals of sustainable development.

The state of the environment has significantly improved in the very short term during the COVID-19 lockdowns in many urban areas. Economic activities and meeting the physical needs of humans are closely related to air pollution. It could be said that air quality is related to the restrictions imposed. Furthermore, the share of the energy mix belonging to fossil fuels decreased in many countries. However, short-term improvements in air pollution will not necessarily affect the long-term state of the environment and air pollution. Emissions from the transport sector during the pandemic depended on the region; in some of those in which restrictions were imposed, environmental pollution from transport was significantly reduced. However, in some regions, e.g., in European countries, emissions have increased more in some countries due to the reduced use of public transport and increased use of private road transport.

The economic uncertainty and other negative effects on the energy sector as a result of the COVID-19 pandemic should not change the path of low-carbon energy. Our society has an ambitious goal to reduce at least $70 \%$ of $\mathrm{CO}_{2}$ emissions compared to today by 2050 [125]. This goal can be achieved by combining renewable energy development and energy efficiency measures. Although various countries in the world are facing challenges in the energy sector caused by the COVID-19 pandemic, the support decisions are crucial [57]. The pandemic caused many difficulties in supply technologies, such as manufacturing and export. Furthermore, the decrease in the profitability of investments in renewable energy projects was determined. Elavarasan et al. [38] analyzed the impact of COVID-19 on the energy sector in seeking sustainability goals. It was found that changes in market, investments and policy have a significant role on the progress towards sustainability in the sector. In order to counteract the negative effects of the COVID-19 pandemic on the profitability of renewable energy projects and promote the investments in renewables, tax policy can play a crucial role.

The COVID-19 pandemic caused a lot of challenges for low-income people, especially those that face a risk of falling into energy poverty, or who already suffer from it. The negative impact on households' disposable income and the increase in prices and expenditure on energy were found by analyzing the newest statistical data of energy users.

The impact to the energy system's flexibility should be discussed more in scientific studies. The decrease in energy use, the change in peak demand, and the increase in renewable energy penetration caused challenges for each country's energy system. Therefore, new projections and models are required to ensure system flexibility.

The review and analysis of empirical studies dealing with the measurement and identification of the COVID-19 pandemic to the sustainability of the energy sector allows us to provide a broad map of the problem and gives solid background for further research. The analysis of the papers also allowed us to identify papers, which proposed the policy measures adopted for mitigating the negative impacts of the COVID-19 pandemic, e.g., $[20,38,54,121,123]$. Therefore, future energy policy should pay particular attention to the changes in energy sector and recent achievement of scientific studies in the field.

\section{Conclusions}

The article deals with the impact of the global pandemic in the energy sector and explores the progress towards sustainability. The systematic literature review was performed in the WoS database and follows recommendations of the SALSA and PRISMA approaches. A total of 113 relevant articles were selected for the analysis, which were categorized ac- 
cording to their application and impact area. It was identified that the pandemic impacted the sustainability of the energy sector through five impact areas.

The changes in energy consumption and energy demand were identified. The recent studies showed that overall energy consumption declined, but energy demand increased in the residential sector, and decreased in the commercial and industrial sectors. In addition, changes in consumption profiles of energy users and time shift in peak demand were observed. A positive impact on air quality and air pollution was found. Furthermore, the analysis of statistical data showed the decrease in share of fossil fuels in energy mix. According to the results of the analysis, fuel consumption reduced in most countries, while the use of private transport increased in Europe. The systematic literature review enabled us to find that the difficulties in technologies supply (manufacturing and export), the decrease in the profitability of investments and economic uncertainty had a negative impact on investments in new renewable energy projects in many countries. Moreover, the negative impacts of the COVID-19 pandemic on the disposable household income and the increase in prices and expenditure on energy were identified. The analysis of previous studies allows us to conclude that decrease in energy use, change in peak demand, and increase in renewable energy penetration caused challenges for each country energy system and new projections and models are required to ensure energy system flexibility.

The energy sector faced a lot of challenges during the pandemic, such as: resource management, energy system reliability and resiliency, changes in energy demand and consumption patterns, changes in energy mix, carbon emissions, uncertainty regarding new renewable energy projects and lower investments. The falling price of crude oil can influence low-carbon energy transition in the post-COVID era, especially in the developing and most-affected countries. The pandemic may have various lasting impacts on the energy sector and the environment at the local, regional and global scale. How long the effects of the pandemic will last, and what the extent will be, depends on many factors and on the response from policy-makers and the measures they implement.

Funding: This research received no external funding.

Institutional Review Board Statement: Not applicable.

Informed Consent Statement: Not applicable.

Data Availability Statement: Not applicable.

Acknowledgments: The author is grateful for the reviewers' comments and valuable suggestions.

Conflicts of Interest: The author declares no conflict of interest.

\section{References}

1. World Health Organization. Coronavirus Disease (COVID-19). 2021. Available online: https://www.who.int/emergencies/ diseases /novel-coronavirus-2019 (accessed on 3 October 2021).

2. Chen, C.; Zarazua de Rubens, G.; Xu, X.; Li, J. Coronavirus comes home? energy use, home energy management, and the social psychological factors of COVID-19. Energy Res. Soc. Sci. 2020, 68, 101688. [CrossRef] [PubMed]

3. Abdeen, A.; Kharvari, F.; O'Brien, W.; Gunay, B. The impact of the COVID-19 on households' hourly electricity consumption in Canada. Energy Build. 2021, 250, 111280. [CrossRef]

4. IEA. Global Energy Review 2020: The Impacts of the COVID-19 Crisis on Global Energy Demand and $\mathrm{CO}_{2}$ Emissions; OECD Publishing: Paris, France, 2020. [CrossRef]

5. Forster, P.M.; Forster, H.I.; Evans, M.J.; Gidden, M.J.; Jones, C.D.; Keller, C.A.; Lamboll, R.D.; Le Quéré, C.; Rogelj, J.; Rosen, D. Current and future global climate impacts resulting from COVID-19. Nat. Clim. Chang. 2020, 10, 913-919. [CrossRef]

6. Sui, Y.; Zhang, H.; Shang, W.; Sun, R.; Wang, C.; Ji, J.; Shao, F. Mining urban sustainable performance: Spatio-temporal emission potential \ changes of urban transit buses in post-COVID-19 future. Appl. Energy 2020, 280, 115966. [CrossRef] [PubMed]

7. Xin, Y.; Shao, S.; Wang, Z.; Xu, Z.; Li, H. COVID-2019 Lockdown in Beijing: A Rare Opportunity to Analyze the Contribution Rate of Road Traffic to Air Pollutants. Sustain. Cities Soc. 2021, 75, 102989. [CrossRef] [PubMed]

8. IEA. World Energy Outlook 2020; IEA: Paris, France, 2020. Available online: https://www.iea.org/reports/world-energy-outlook2020 (accessed on 20 October 2021).

9. Bompard, E.; Mosca, C.; Colella, P.; Antonopoulos, G.; Fulli, G.; Masera, M.; Poncela-Blanco, M.; Vitiello, S. The Immediate Impacts of COVID-19 on European Electricity Systems: A First Assessment and Lessons Learned. Energies 2021, 14, 96. [CrossRef] 
10. Zhong, H.W.; Tan, Z.F.; He, Y.L.; Xie, L.; Kang, C.Q. Implications of COVID-19 for the Electricity Industry: A Comprehensive Review. CSEE J. Power Energy Syst. 2021, 6, 489-495.

11. Werth, A.; Gravino, P.; Prevedello, G. Impact analysis of COVID-19 responses on energy grid dynamics in Europe. Appl. Energy 2021, 281, 116045. [CrossRef]

12. Navon, A.; Machlev, R.; Carmon, D.; Onile, A.E.; Belikov, J.; Levron, Y. Effects of the COVID-19 Pandemic on Energy Systems and Electric Power Grids-A Review of the Challenges Ahead. Energies 2021, 14, 1056. [CrossRef]

13. Grant, M.J.; Booth, A. A typology of reviews: An analysis of 14 review types and associated methodologies. Health Info. Libr. J. 2009, 26, 91-108.

14. Moher, D.; Liberati, A.; Tetzlaff, J.; Altman, D.G. Preferred reporting items for systematic reviews and meta-analyses: The PRISMA statement. Int. J. Surg. 2010, 8, 336-341. [CrossRef]

15. Rashedi, A.; Khanam, T.; Jonkman, M. On Reduced Consumption of Fossil Fuels in 2020 and Its Consequences in Global Environment and Exergy Demand. Energies 2020, 13, 6048. [CrossRef]

16. Su, C.; Urban, F. Circular economy for clean energy transitions: A new opportunity under the COVID-19 pandemic. Appl. Energy 2021, 289, 116666. [CrossRef]

17. Martinez-Soto, A.; Vera, C.C.A.; Boso, A.; Hofflinger, A.; Shupler, M. Energy poverty influences urban outdoor air pollution levels during COVID-19 lockdown in south-central Chile. Energy Policy 2021, 158, 112571. [CrossRef] [PubMed]

18. Shah, M.I.; Adedoyin, F.F.; Kirikkaleli, D. An evaluation of the causal effect between air pollution and renewable electricity production in Sweden: Accounting for the effects of COVID-19. Int. J. Energy Res. 2021, 45, 18613-18630. [CrossRef] [PubMed]

19. Tudor, C.; Anghel, A. The Financialization of Crude Oil Markets and Its Impact on Market Efficiency: Evidence from the Predictive Ability and Performance of Technical Trading Strategies. Energies 2021, 14, 4485. [CrossRef]

20. Jia, Z.J.; Wen, S.Y.; Lin, B.Q. The effects and reacts of COVID-19 pandemic and international oil price on energy, economy, and environment in China. Appl. Energy 2021, 302, 117612. [CrossRef]

21. Sotnyk, I.; Kurbatova, T.; Kubatko, O.; Prokopenko, O.; Prause, G.; Kovalenko, Y.; Trypolska, G.; Pysmenna, U. Energy Security Assessment of Emerging Economies under Global and Local Challenges. Energies 2021, 14, 5860. [CrossRef]

22. Ghenai, C.; Bettayeb, M. Data analysis of the electricity generation mix for clean energy transition during COVID-19 lockdowns. Energy Sources Part A Recovery Util. Environ. EFF 2021, 1-21. [CrossRef]

23. Shupler, M.; Mwitari, J.; Gohole, A.; de Cuevas, R.A.; Puzzolo, E.; Cukic, I.; Nix, E.; Pope, D. COVID-19 impacts on household energy \& food security in a Kenyan informal settlement: The need for integrated approaches to the SDGs. Renew. Sustain. Energy Rev. 2021, 144, 111018.

24. Wang, Q.Q.; Lu, M.; Bai, Z.M.; Wang, K. Coronavirus pandemic reduced China's $\mathrm{CO}_{2}$ emissions in short-term, while stimulus packages may lead to emissions growth in medium- and long-term. Appl. Energy 2020, 278, 115735. [CrossRef] [PubMed]

25. Lalas, D.; Gakis, N.; Mirasgedis, S.; Georgopoulou, E.; Sarafidis, Y.; Doukas, H. Energy and GHG Emissions Aspects of the COVID Impact in Greece. Energies 2021, 14, 1955. [CrossRef]

26. Zhang, D.D.; Li, H.Y.; Zhu, H.Y.; Zhang, H.C.; Goh, H.H.; Wong, M.C.; Wu, T. Impact of COVID-19 on Urban Energy Consumption of Commercial Tourism City. Sustain. Cities Soc. 2021, 73, 103133. [CrossRef]

27. Alhajeri, H.M.; Almutairi, A.; Alenezi, A.; Alshammari, F. Energy Demand in the State of Kuwait During the Covid-19 Pandemic: Technical, Economic, and Environmental Perspectives. Energies 2020, 13, 4370. [CrossRef]

28. Bento, P.M.R.; Mariano, S.J.P.S.; Calado, M.R.A.; Pombo, J.A.N. Impacts of the COVID-19 pandemic on electric energy load and pricing in the Iberian electricity market. Energy Rep. 2021, 7, 4833-4849. [CrossRef]

29. Huang, R.; Tian, L.X. $\mathrm{CO}_{2}$ emissions inequality through the lens of developing countries. Appl. Energy 2021, $281,116043$. [CrossRef]

30. Maniatis, K.; Chiaramonti, D.; van den Heuvel, E. Post COVID-19 Recovery and 2050 Climate Change Targets: Changing the Emphasis from Promotion of Renewables to Mandated Curtailment of Fossil Fuels in the EU Policies. Energies 2021, $14,1347$. [CrossRef]

31. Teske, S.; Pregger, T.; Simon, S.; Naegler, T.; Pagenkopf, J.; Deniz, O.; van den Adel, B.; Dooley, K.; Meinshausen, M. It Is Still Possible to Achieve the Paris Climate Agreement: Regional, Sectoral, and Land-Use Pathways. Energies 2021, 14, 2103. [CrossRef]

32. Rochedo, P.R.R.; Fragkos, P.; Garaffa, R.; Couto, L.C.; Baptista, L.B.; Cunha, B.S.L.; Schaeffer, R.; Szklo, A. Is Green Recovery Enough? Analysing the Impacts of Post-COVID-19 Economic Packages. Energies 2021, 14, 5567. [CrossRef]

33. Maestosi, P.C.; Andreucci, M.B.; Civiero, P. Sustainable Urban Areas for 2030 in a Post-COVID-19 Scenario: Focus on Innovative Research and Funding Frameworks to Boost Transition towards 100 Positive Energy Districts and 100 Climate-Neutral Cities. Energies 2021, 14, 216. [CrossRef]

34. Dmytrow, K.; Landmesser, J.; Bieszk-Stolorz, B. The Connections between COVID-19 and the Energy Commodities Prices: Evidence through the Dynamic Time Warping Method. Energies 2021, 14, 4024. [CrossRef]

35. Bazzana, D.; Cohen, J.J.; Golinucci, N.; Hafner, M.; Noussan, M.; Reichl, J.; Rocco, M.V.; Sciullo, A.; Vergalli, S. A multi-disciplinary approach to estimate the medium-term impact of COVID-19 on transport and energy: A case study for Italy. Energy 2022, 238, 122015. [CrossRef] [PubMed]

36. Klemes, J.J.; Van Fan, Y.; Jiang, P. The energy and environmental footprints of COVID-19 fighting measures—PPE, disinfection, supply chains. Energy 2020, 211, 118701. [CrossRef] [PubMed] 
37. Jiang, P.; Klemes, J.J.; Fan, Y.V.; Fu, X.J.; Tan, R.R.; You, S.M.; Foley, A.M. Energy, environmental, economic and social equity (4E) pressures of COVID-19 vaccination mismanagement: A global perspective. Energy 2021, 235, 121315. [CrossRef]

38. Elavarasan, R.M.; Pugazhendhi, R.; Jamal, T.; Dyduch, J.; Arif, M.T.; Kumar, N.M.; Shafiullah, G.M.; Chopra, S.S.; Nadarajah, M. Envisioning the UN Sustainable Development Goals (SDGs) through the lens of energy sustainability (SDG 7) in the post-COVID19 world. Appl. Energy 2021, 292, 116665. [CrossRef]

39. Gurbuz, H.; Sohret, Y.; Ekici, S. Evaluating effects of the Covid-19 pandemic period on energy consumption and enviro-economic indicators of Turkish road transportation. Energy Sources Part A Recovery Util. Environ. Eff. 2021, 1-13. [CrossRef]

40. Styring, P.; Duckworth, E.L.; Platt, E.G. Synthetic Fuels in a Transport Transition: Fuels to Prevent a Transport Underclass. Front. Energy Res. 2021, 9, 707867. [CrossRef]

41. Kylili, A.; Afxentiou, N.; Georgiou, L.; Panteli, C.; Morsink-Georgalli, P.Z.; Panayidou, A.; Papouis, C.; Fokaides, P.A. The role of Remote Working in smart cities: Lessons learnt from COVID-19 pandemic. Energy Sources Part A-Recovery Util. Environ. Eff. 2020, 1-16. [CrossRef]

42. Nizetic, S. Impact of coronavirus (COVID-19) pandemic on air transport mobility, energy, and environment: A case study. Int. J. Energy Res. 2020, 44, 10953-10961. [CrossRef]

43. Schulte-Fischedick, M.; Shan, Y.L.; Hubacek, K. Implications of COVID-19 lockdowns on surface passenger mobility and related $\mathrm{CO}_{2}$ emission changes in Europe. Appl. Energy 2021, 300, 117396. [CrossRef]

44. Griffiths, S.; Del Rio, D.F.; Sovacool, B. Policy mixes to achieve sustainable mobility after the COVID-19 crisis. Renew. Sustain. Energy Rev. 2021, 143, 110919. [CrossRef]

45. Wang, K.; Wang, Y.W.; Chang, C.P. The impacts of COVID-19 pandemic on air pollution from energy consumption: Diverse evidence from China. Int. J. Green Energy 2021, 1-11. [CrossRef]

46. Gebreslassie, M.G. Comparative assessment of the challenges faced by the solar energy industry in Ethiopia before and during the COVID-19 pandemic. Wiley Interdiscipli. Rev. Energy Environ. 2021, e418. [CrossRef] [PubMed]

47. Yu, B.Y.; Zhao, Z.H.; Zhao, G.P.; An, R.Y.; Sun, F.H.; Li, R.; Peng, X.H. Provincial renewable energy dispatch optimization in line with Renewable Portfolio Standard policy in China. Renew. Energy 2021, 174, 236-252. [CrossRef]

48. Hoang, A.T.; Nguyen, X.P.; Le, A.T.; Huynh, T.T.; Pham, V.V. COVID-19 and the Global Shift Progress to Clean Energy. J. Energy Resour. Technol. Trans. ASME 2021, 143, 94701. [CrossRef]

49. Hoang, A.T.; Nizetic, S.; Olcer, A.I.; Ong, H.C.; Chen, W.H.; Chong, C.T.; Thomas, S.; Bandh, S.A.; Nguyen, X.P. Impacts of COVID-19 pandemic on the global energy system and the shift progress to renewable energy: Opportunities, challenges, and policy implications. Energy Policy 2021, 154, 112322. [CrossRef] [PubMed]

50. Shah, M.I.; Kirikkaleli, D.; Adedoyin, F.F. Regime switching effect of COVID-19 pandemic on renewable electricity generation in Denmark. Renew. Energy 2021, 175, 797-806. [CrossRef]

51. Kudelin, A.; Kutcherov, V. Wind Energy in Russia: The current state and development trends. Energy Strategy Rev. 2021, $34,100627$. [CrossRef]

52. Ziemba, P. Multi-Criteria Fuzzy Evaluation of the Planned Offshore Wind Farm Investments in Poland. Energies 2021, 14, 978. [CrossRef]

53. Andiappan, V.; How, B.S.; Ngan, S.L. A Perspective on Post-Pandemic Biomass Supply Chains: Opportunities and Challenges for the New Norm. Process Integr. Optim. Sustain. 2021, 5, 1003-1010. [CrossRef]

54. Wang, W.H.; Moreno-Casas, V.; de Soto, J.H. A Free-Market Environmentalist Transition Toward Renewable Energy: The Cases of Germany, Denmark, and the United Kingdom. Energies 2021, 14, 4659. [CrossRef]

55. Sahin, U.; Balli, S.; Chen, Y. Forecasting seasonal electricity generation in European countries under Covid-19-induced lockdown using fractional grey prediction models and machine learning methods. Appl. Energy 2021, 302, 117540. [CrossRef]

56. Kougias, I.; Taylor, N.; Kakoulaki, G.; Jager-Waldau, A. The role of photovoltaics for the European Green Deal and the recovery plan. Renew. Sustain. Energy Rev. 2021, 144, 111017. [CrossRef]

57. Fu, J.Y.; Ng, A.W. Scaling up Renewable Energy Assets: Issuing Green Bond via Structured Public-Private Collaboration for Managing Risk in an Emerging Economy. Energies 2021, 14, 3076. [CrossRef]

58. Liu, X.L.; Lin, Z. Impact of COVID-19 pandemic on electricity demand in the UK based on multivariate time series forecasting with Bidirectional Long Short Term Memory. Energy 2021, 227, 120455. [CrossRef]

59. Tsai, W.T. Impact of COVID-19 on energy use patterns and renewable energy development in Taiwan. Energy Sources Part A Recovery Util. Environ. Eff. 2021, 1-11. [CrossRef]

60. Pradhan, S.; Ghose, D.; Shabbiruddin. Present and future impact of COVID-19 in the renewable energy sector: A case study on India. Energy Sources Part A-Recovery Util. Environ. Eff. 2020, 1-11. [CrossRef]

61. Wang, C.; Huang, X.; Hu, X.Q.; Zhao, L.F.; Liu, C.; Ghadimi, P. Trade characteristics, competition patterns and COVID-19 related shock propagation in the global solar photovoltaic cell trade. Appl. Energy 2021, 290, 116744. [CrossRef]

62. Tu, Q.; Mo, J.L.; Liu, Z.R.; Gong, C.X.; Fan, Y. Using green finance to counteract the adverse effects of COVID-19 pandemic on renewable energy investment-The case of offshore wind power in China. Energy Policy 2021, 158, 112542. [CrossRef]

63. Hemrit, W.; Benlagha, N. Does renewable energy index respond to the pandemic uncertainty? Renew. Energy 2021, 177, 336-347. [CrossRef]

64. Shekhar, J.; Suri, D.; Somani, P.; Lee, S.J.; Arora, M. Reduced renewable energy stability in India following COVID-19: Insights and key policy recommendations. Renew. Sustain. Energy Rev. 2021, 144, 111015. [CrossRef] 
65. Zhang, H.R.; Yan, J.Y.; Yu, Q.; Obersteiner, M.; Li, W.J.; Chen, J.Y.; Zhang, Q.; Jiang, M.K.; Wallin, F.; Song, X.; et al. 1.6 Million transactions replicate distributed PV market slowdown by COVID-19 lockdown. Appl. Energy 2021, 283, 116341. [CrossRef]

66. Zeinalnezhad, M.; Chofreh, A.G.; Goni, F.A.; Hashemi, L.S.; Klemes, J.J. A hybrid risk analysis model for wind farms using Coloured Petri Nets and interpretive structural modelling. Energy 2021, 229, 120696. [CrossRef]

67. Saif-Alyousfi, A.Y.H.; Saha, A. The impact of COVID-19 and non-pharmaceutical interventions on energy returns worldwide. Sustain. Cities Soc. 2021, 70, 102943. [CrossRef]

68. Mohideen, M.M.; Ramakrishna, S.; Prabu, S.; Liu, Y. Advancing green energy solution with the impetus of COVID-19 pandemic. J. Energy Chem. 2021, 59, 688-705. [CrossRef]

69. Schwidtal, J.M.; Agostini, M.; Bignucolo, F.; Coppo, M.; Garengo, P.; Lorenzoni, A. Integration of Flexibility from Distributed Energy Resources: Mapping the Innovative Italian Pilot Project UVAM. Energies 2021, 14, 1910. [CrossRef]

70. Bejger, S. Competition in a Wholesale Fuel Market-The Impact of the Structural Changes Caused by COVID-19. Energies 2021, 14, 4211. [CrossRef]

71. Nyga-Lukaszewska, H.; Aruga, K. Energy Prices and COVID-Immunity: The Case of Crude Oil and Natural Gas Prices in the US and Japan. Energies 2020, 13, 6300. [CrossRef]

72. Rajan, D.V.; Indira, A.; Devarapalli, R.; Thakur, S.S. Lockdown impact on power systems based on experience curves and complementary bottom-up assessments during COVID-19. Energy Sources Part A Recovery Util. Environ. Eff. 2021, 1-28. [CrossRef]

73. Iancu, I.A.; Darab, C.P.; Cirstea, S.D. The Effect of the COVID-19 Pandemic on the Electricity Consumption in Romania. Energies 2021, 14, 3146. [CrossRef]

74. Xu, A.T.; Gao, B.W.; Li, C.Y.; Qian, D.F. Impact of the COVID-19 pandemic on the reduction of electricity demand and the integration of renewable energy into the power grid. J. Renew. Sustain. Energy 2021, 13, 26304.

75. Halbrugge, S.; Schott, P.; Weibelzahl, M.; Buhl, H.U.; Fridgen, G.; Schopf, M. How did the German and other European electricity systems react to the COVID-19 pandemic? Appl. Energy 2021, 285, 116370. [CrossRef]

76. Drabecki, M.P.; Kulak, K.B. Global Pandemics on European Electrical Energy Markets: Lessons Learned from the COVID-19 Outbreak. Int. J. Energy Optim. Eng. 2021, 10, 24-46. [CrossRef]

77. Ghiani, E.; Galici, M.; Mureddu, M.; Pilo, F. Impact on Electricity Consumption and Market Pricing of Energy and Ancillary Services during Pandemic of COVID-19 in Italy. Energies 2020, 13, 3357. [CrossRef]

78. Kirli, D.; Parzen, M.; Kiprakis, A. Impact of the COVID-19 Lockdown on the Electricity System of Great Britain: A Study on Energy Demand, Generation, Pricing and Grid Stability. Energies 2021, 14, 635. [CrossRef]

79. Han, L.; Zhao, J.Y.; Gu, Z.L. Assessing air quality changes in heavily polluted cities during the COVID-19 pandemic: A case study in Xi'an, China. Sustain. Cities Soc. 2021, 70, 102934. [CrossRef]

80. Shang, W.L.; Chen, J.Y.; Bi, H.B.; Sui, Y.; Chen, Y.Y.; Yu, H.T. Impacts of COVID-19 pandemic on user behaviors and environmental benefits of bike sharing: A big-data analysis. Appl. Energy 2021, 285, 116429. [CrossRef]

81. Bielecki, S.; Skoczkowski, T.; Sobczak, L.; Buchoski, J.; Maciag, L.; Dukat, P. Impact of the Lockdown during the COVID-19 Pandemic on Electricity Use by Residential Users. Energies 2021, 14, 980. [CrossRef]

82. Rouleau, J.; Gosselin, L. Impacts of the COVID-19 lockdown on energy consumption in a Canadian social housing building. Appl. Energy 2021, 287, 116565. [CrossRef]

83. Liu, A.R.; Miller, W.; Crompton, G.; Zedan, S. Has COVID-19 lockdown impacted on aged care energy use and demand? Energy Build. 2021, 235, 110759. [CrossRef]

84. Carvalho, M.; de Delgado, D.B.; de Lima, K.M.; de Cancela, M.; dos Siqueira, C.A.; de Souza, D.L.B. Effects of the COVID-19 pandemic on the Brazilian electricity consumption patterns. Int. J. Energy Res. 2021, 45, e5877. [CrossRef]

85. Zanocco, C.; Flora, J.; Rajagopal, R.; Boudet, H. Exploring the effects of California's COVID-19 shelter-in-place order on household energy practices and intention to adopt smart home technologies. Renew. Sustain. Energy Rev. 2021, 139, 110578. [CrossRef] [PubMed]

86. Snow, S.; Bean, R.; Glencross, M.; Horrocks, N. Drivers behind Residential Electricity Demand Fluctuations Due to COVID-19 Restrictions. Energies 2020, 13, 5738. [CrossRef]

87. Alkhraijah, M.; Alowaifeer, M.; Alsaleh, M.; Alfaris, A.; Molzahn, D.K. The Effects of Social Distancing on Electricity Demand Considering Temperature Dependency. Energies 2021, 14, 473. [CrossRef]

88. Chen, C.F.; Nelson, H.; Xu, X.J.; Bonilla, G.; Jones, N. Beyond technology adoption: Examining home energy management systems, energy burdens and climate change perceptions during COVID-19 pandemic. Renew. Sustain. Energy Rev. 2021, 145, 111066. [CrossRef]

89. Kang, H.; An, J.; Kim, H.; Ji, C.; Hong, T.; Lee, S. Changes in energy consumption according to building use type under COVID-19 pandemic in South Korea. Renew. Sustain. Energy Rev. 2021, 148, 111294. [CrossRef]

90. Garcia, S.; Parejo, A.; Personal, E.; Guerrero, J.I.; Biscarri, F.; Leon, C. A retrospective analysis of the impact of the COVID-19 restrictions on energy consumption at a disaggregated level. Appl. Energy 2021, 287, 116547. [CrossRef]

91. Qarnain, S.S.; Sattanathan, M.; Sankaranarayanan, B.; Ali, S.M. Analyzing energy consumption factors during coronavirus (COVID-19) pandemic outbreak: A case study of residential society. Energy Sources Part A Recovery Util. Environ. Eff. 2020, 1-20. [CrossRef]

92. Malec, M.; Kinelski, G.; Czarnecka, M. The Impact of COVID-19 on Electricity Demand Profiles: A Case Study of Selected Business Clients in Poland. Energies 2021, 14, 5332. [CrossRef] 
93. Oliva, A.; Gracceva, F.; Lerede, D.; Nicoli, M.; Savoldi, L. Projection of Post-Pandemic Italian Industrial Production through Vector Auto Regressive Models. Energies 2021, 14, 5458. [CrossRef]

94. Geraldi, M.S.; Bavaresco, M.V.; Triana, M.A.; Melo, A.P.; Lamberts, R. Addressing the impact of COVID-19 lockdown on energy use in municipal buildings: A case study in Florian? opolis, Brazil. Sustain. Cities Soc. 2021, 69, 102823. [CrossRef] [PubMed]

95. Corticos, N.D.; Duarte, C.C. COVID-19: The impact in US high-rise office buildings energy efficiency. Energy Build. 2021, 249, 111180. [CrossRef] [PubMed]

96. Strielkowski, W.; Firsova, I.; Lukashenko, I.; Raudeliuniene, J.; Tvaronaviciene, M. Effective Management of Energy Consumption during the COVID-19 Pandemic: The Role of ICT Solutions. Energies 2021, 14, 893. [CrossRef]

97. Hauser, P.; Schonheit, D.; Scharf, H.; Anke, C.P.; Most, D. Covid-19's Impact on European Power Sectors: An Econometric Analysis. Energies 2021, 14, 1639. [CrossRef]

98. Abadie, L.M. Energy Market Prices in Times of COVID-19: The Case of Electricity and Natural Gas in Spain. Energies 2021, 14, 1632. [CrossRef]

99. Norouzi, N.; de Rubens, G.Z.Z.; Enevoldsen, P.; Forough, A.B. The impact of COVID-19 on the electricity sector in Spain: An econometric approach based on prices. Int. J. Energy Res. 2021, 45, 6320-6332. [CrossRef]

100. Soava, G.; Mehedintu, A.; Sterpu, M.; Grecu, E. The Impact of the COVID-19 Pandemic on Electricity Consumption and Economic Growth in Romania. Energies 2021, 14, 2394. [CrossRef]

101. Sozen, A.; Izgec, M.M.; Kirbas, I.; Kazancioglu, F.S.; Tuncer, A.D. Overview, modeling and forecasting the effects of COVID-19 pandemic on energy market and electricity demand: A case study on Turkey. Energy Sources Part A Recovery Util. Environ. EFF 2021, 1-16. [CrossRef]

102. Ceylan, Z. The impact of COVID-19 on the electricity demand: A case study for Turkey. Int. J. Energy Res. 2021, 45, 13022-13039. [CrossRef]

103. Bin Amin, S.; Ahmed, A.; Khan, A.M.; Khan, F. Policy Paper on the Post Covid-19 Sustainable Energy Options for Power Generation in Bangladesh. Int. Energy J. 2021, 21, 9-19.

104. Kim, D.; Yim, T.; Lee, J.Y. Analytical study on changes in domestic hot water use caused by COVID-19 pandemic. Energy 2021, 231, 120915. [CrossRef] [PubMed]

105. Lu, H.F.; Ma, X.; Ma, M.D. A hybrid multi-objective optimizer-based model for daily electricity demand prediction considering COVID-19. Energy 2021, 219, 119568. [CrossRef] [PubMed]

106. Cvetkovic, D.; Nesovic, A.; Terzic, I. Impact of people's behavior on the energy sustainability of the residential sector in emergency situations caused by COVID-19. Energy Build. 2021, 230, 110532. [CrossRef] [PubMed]

107. Mauritzen, J. The Covid-19 shock on a low-carbon grid: Evidence from the nordics. Energy Policy 2021, 156, 112416. [CrossRef]

108. Klemes, J.J.; Jiang, P.; Van Fan, Y.; Bokhari, A.; Wang, X.C. COVID-19 pandemics Stage II—Energy and environmental impacts of vaccination. Renew. Sustain. Energy Rev. 2021, 150, 111400. [CrossRef]

109. Mamica, L.; Glowacki, J.; Makiela, K. Determinants of the Energy Poverty of Polish Students during the COVID-19 Pandemic. Energies 2021, 14, 3233. [CrossRef]

110. Chiaramonti, D.; Maniatis, K. Security of supply, strategic storage and Covid19: Which lessons learnt for renewable and recycled carbon fuels, and their future role in decarbonizing transport? Appl. Energy 2020, 271, 115216. [CrossRef]

111. Olubusoye, O.E.; Ogbonna, A.E.; Yaya, O.S.; Umolo, D. An information-based index of uncertainty and the predictability of energy prices. Int. J. Energy Res. 2021, 45, 10235-10249. [CrossRef]

112. Hu, S.L.; Li, R.R. Investigating the Effects of the United States' Economic Slowdown Related to the COVID-19 Pandemic on Energy Consumption in Other Countries-A Global Vector Autoregressive Model. Energies 2021, 14, 2984. [CrossRef]

113. Huang, L.Q.; Liao, Q.; Qiu, R.; Liang, Y.T.; Long, Y. Prediction-based analysis on power consumption gap under long-term emergency: A case in China under COVID-19. Appl. Energy 2021, 283, 116339. [CrossRef]

114. Hu, J.W.; Javaid, A.; Creutzig, F. Leverage points for accelerating adoption of shared electric cars: Perceived benefits and environmental impact of NEVs. Energy Policy 2021, 155, 112349. [CrossRef]

115. Nagaj, R.; Korpysa, J. Impact of COVID-19 on the Level of Energy Poverty in Poland. Energies 2020, 13, 4977. [CrossRef]

116. Memmott, T.; Carley, S.; Graff, M.; Konisky, D.M. Sociodemographic disparities in energy insecurity among low-income households before and during the COVID-19 pandemic. Nat. Energy 2021, 6, 186-193. [CrossRef]

117. Ambrose, A.; Baker, W.; Sherriff, G.; Chambers, J. Cold comfort: Covid-19, lockdown and the coping strategies of fuel poor households. Energy Rep. 2021, 7, 5589-5596. [CrossRef]

118. Graff, M.; Carley, S. COVID-19 assistance needs to target energy insecurity. Nat. Energy 2020, 5, 352-354. [CrossRef]

119. Bienvenido-Huertas, D. Do unemployment benefits and economic aids to pay electricity bills remove the energy poverty risk of Spanish family units during lockdown? A study of COVID-19-induced lockdown. Energy Policy 2021, 150, 112117. [CrossRef]

120. De Blasis, R.; Petroni, F. Price Leadership and Volatility Linkages between Oil and Renewable Energy Firms during the COVID-19 Pandemic. Energies 2021, 14, 2608. [CrossRef]

121. Heffron, R.J.; Korner, M.F.; Schopf, M.; Wagner, J.; Weibelzahl, M. The role of flexibility in the light of the COVID-19 pandemic and beyond: Contributing to a sustainable and resilient energy future in Europe. Renew. Sustain. Energy Rev. 2021, 140, 110743. [CrossRef]

122. Alvarez, G.E. A multi-objective formulation of improving flexibility in the operation of electric power systems: Application to mitigation measures during the coronavirus pandemic. Energy 2021, 227, 120471. [CrossRef] 
123. Luo, S.H.; Hu, W.H.; Liu, W.; Liu, Z.; Huang, Q.; Chen, Z. Flexibility enhancement measures under the COVID-19 pandemicA preliminary comparative analysis in Denmark, the Netherlands, and Sichuan of China. Energy 2022, 239, 122166. [CrossRef]

124. Huang, Y.R.; Li, S.H.; Wang, R.; Zhao, Z.J.; Huang, B.; Wei, B.; Zhu, G.M. Forecasting Oil Demand with the Development of Comprehensive Tourism. Chem. Technol. Fuels Oils 2021, 57, 299-310. [CrossRef]

125. IRENA. Global Renewables Outlook: Energy Transformation 2050; Edition: 2020; International Renewable Energy Agency: Abu Dhabi, United Arab Emirates, 2020; ISBN 978-92-9260-238-3. Available online: https:/ /www.irena.org/publications/2020/Apr/ Global-Renewables-Outlook-2020 (accessed on 5 October 2021). 